Cómo citar este artículo en APA: González Gaviria, L. (2019). La recuperación de la dimensión escatológica de la historia. Una lectura de la Conferencia de Medellín para el siglo XXI. Cuestiones Teológicas, 46 (105), 29-73.

doi: http://dx.doi.org/10.18566/cueteo.v46n105.a02

Fecha de recepción: 27.11 .2018

Fecha de aceptación: 11.01.2019

\title{
LA RECUPERACIÓN
}

DE LA DIMENSIÓN ESCATOLÓGICA

DE LA HISTORIA.

UNA LECTURA DE LA

CONFERENCIA DE MEDELLÍN

PARA EL SIGLO XXI ${ }^{\mathrm{I}}$

\author{
Recovery of the Eschatological Dimension of History. \\ A Reading of Medellin Conference for the Twenty-First Century \\ A recuperação da dimensão escatológica da história. \\ Uma leitura da conferência de Medellín para 0 século xxı
}

Luis Fernando GonZÁlez GaViria²

1 El presente artículo es el resultado de la investigación hecha para optar al título de Magíster en Teología.

2 Teólogo de la Universidad Católica Luis Amigó (Medellín). Magíster en Teología de la Universidad Pontificia Bolivariana (Medellín). Actualmente se desempeña como profesor de Antropología en la Universidad de San Buenaventura (Medellín).

Correo electrónico: kabod712@gmail.com 


\section{Resumen}

El quehacer teológico del siglo XX ha recuperado la Escatología. Recuperación que no es repetición, sino discontinuidad, lo cual permite vincularla directamente con la historia del ser humano. Uno de los despojos que ha realizado este tratado teológico es abandonar el excesivo lenguaje meta-histórico, propio de la neoescolástica, que desarticula la Escatología de la realidad. Es aquí donde la Conferencia de Medellín logra que la reflexión escatológica se piense, se proponga y se viva rescatando el gusto por las "penúltimas cosas", haciendo de la realidad misma del ser humano el lugar primado del acontecimiento de Dios, siempre en clave de Encarnación, orientada hacia su plenitud. La Escatología en Medellín es histórica, encarnada y acontecida en el interior del mundo. Esta reflexión consta de tres momentos: Medellín como receptor de un legado teológico, Medellín y su concepción de la Escatología y la Escatología como acontecer histórico-salvífico. Mediante el acercamiento al texto de manera analítica y crítica, se llega a una hermenéutica actualizada, mostrando con ello que Medellín abrió un camino nuevo para captar existencialmente la Escatología, camino que es historia como Encarnación.

Palabras clave: Medellín, Escatología, Historia, Liberación, Salvación.

\section{Abstract}

Theological practice during the twentieth century has recovered Eschatology. Such recovery is not repetition, but discontinuity, which makes possible to link it directly to the history of the human being. This theological work has allowed abandoning the excessive metahistorical language, typical of NeoScholasticism, which disarticulates the Eschatology of reality. It is precisely in this point that Medellin Conference makes possible for eschatological reflection to be thought of, proposed and lived. The latter is done by rescuing the taste for "next-to-last things", making the very reality of human beings the primal place of God's happening -always in the light of Incarnation-, and by orienting it towards their fulfillment. Thus, Eschatology in Medellin Conference is historical, incarnated and happening within the world. The article has three 
parts: Medellin as inheriting a theological legacy, Medellin and its view of Eschatology, and Eschatology as a historical-salvific happening. Through an analytical and critical approach to the conference, an updated hermeneutic is developed, which shows that Medellin opened a new path to existentially grasp Eschatology, a path that is history as Incarnation.

Key Words: Medellin, Eschatology, History, Liberation, Salvation.

\section{Resumo}

A tarefa teológica do século XX tem recuperado a Escatologia. Essa recuperaçáo não é repetição, mas sim descontinuidade, o que permite aproxima-la diretamente à história do ser humano. Um dos espólios que esse tratado teológico tem realizado consiste em abandonar a excessiva linguagem metahistórica, própria da neoescolástica, que separa a escatologia da realidade. Eis onde a Conferência de Medellín consegue que a reflexão escatológica se pense, proponha e viva segundo o gosto das "penúltimas coisas", por conseguinte a realidade do ser humano se torna o lugar principal do acontecimento de Deus em termos de encarnação e para sua plenitude. A escatologia em Medellín é histórica, encarnada e tem acontecido ao interior do mundo. Essa reflexão tem três momentos: Medellín como destinatário de uma herança teológica, Medellín e sua conceição da escatologia e a escatologia como acontecimento histórico-salvífico. A partir de uma abordagem analítica e critica do texto se chega a uma hermenêutica atualizada, é por isso que Medellín abriu um caminho novo para identificar existencialmente a escatologia, caminho que é história como encarnação.

Palavras chave: Medellín, escatologia, história, liberação, salvação. 


\title{
Introducción. Medellín: recepción de una historia
}

\author{
"Tenemos fe: en Dios, en los hombres, en los valores \\ y en el futuro de América Latina”. \\ Mensaje final a los pueblos de América Latina
}

La Escatología quedó por mucho tiempo relegada a un segundo plano en la historia del quehacer teológico, se hacía referencia a ella desde la simpleza y lo establecido como dogma definitivo, pensar más allá era un atrevimiento y una ofensa a lo determinado. La reducción escatológica a simple tratado, trajo consigo la nefasta percepción de unas realidades que se abrían en el horizonte del ser humano en términos de premio o castigo. La Escatología concebida de esta manera habría que dejarla de lado, pues nada tenía de vinculante para el ser humano; el desenlace definitivo de su vida parecía más un juicio inquisitorio que una Buena Noticia.

Respecto a lo anterior, el excesivo lenguaje meta-histórico propio de la neoescolástica desarticula la Escatología de la realidad, presentándola como un conjunto de verdades abstractas que el creyente profesa sin más. Estas situaciones han hecho que la Escatología no sea comprendida dentro del acontecimiento encarnacionista de Jesús, Hombre en la historia, sino desde la Pascua como punto de llegada y esperanza de un final en "otra-parte".

El siglo XX fue el "aggiornamento" de la teología. Los teólogos se arriesgaron a "repensar" todo el constructo histórico de lo que se había hecho y que estaba desembocando en la imperante teología neoescolástica. Era el momento de devolverle a la teología su realidad evangélica y su vinculación directa con la historia del ser humano ${ }^{3}$. De esta manera, "el desplazamiento de la teología desde un enfoque metafísico a uno histórico-salvífico crea

3 La fecundidad del cambio necesario que se tornaba urgente se hace a partir de cuatro momentos, según el padre Adolfo Galeano (2013), los cuales se convierten en bases fuertes para que el progreso teológico tuviera éxito, a saber, "la crisis de la metafísica y el fin de la neoescolástica, la revolución científica y tecnológica, el cambio y la crítica operados por la Nouvelle Théologie y el cambio de paradigma: del griego al bíblico" (p. 345). 
nuevos planteamientos fecundos para el progreso teológico" (Galeano, 2013, p. 352).

Dentro de este panorama, la Escatología ${ }^{4}$ cobra protagonismo, deja de estar relegada al mito final pasando al primer plano del quehacer teológico. Así pues, se da una recuperación que parte de la pregunta por la historia y su relación con la revelación y la fe, de ahora en adelante "la recuperación de la historia era la nueva tarea confiada a la teología" (Gibellini, 1998, p. 271). Partiendo de esta tarea, la Escatología dejará de ser palabra sospechosa sobre el más allá, y se situará en la existencia real e histórica del ser humano habitado por Dios.

Los principales hacedores de la recuperación histórica dentro de la reflexión teológica, y con ella, el redescubrimiento de la Escatología, son: Oscar Cullman y su teología de la historia de la salvación a partir de su libro Cristo y el tiempo (1946),

la intención de su obra no era estudiar la esencia del tiempo en la concepción bíblica o, más concretamente, en la concepción neotestamentaria, sino más bien, la búsqueda del elemento central del mensaje cristiano. Y la solución se formula así: Dios se revela en una historia de la salvación (Gibellini, 1998, p. 272).

Otro de los grandes aportes a la teología de la historia lo hace Jean Daniélou en su ensayo El misterio de la historia (1953). La base fundamental de escrito estriba en que Daniélou,

prefiere hablar de historia sagrada (histoire sainte) mejor que de historia de la salvación, y la presenta como historia total, en la que va a confluir la

4 Rosino Gibellini expone de manera precisa cómo se va dando la recuperación de la Escatología en su obra La teología del siglo XX (1998). A propósito de esto dice: uno de los rasgos característicos de la teología del siglo XX es el redescubrimiento del carácter escatológico del cristianismo. La escatología había sido reducida una "doctrina de los novísimos", como doctrina de las realidades últimas, que había que desarrollar sectorialmente y, a lo sumo, como apéndice final después de tratar e las demás verdades cristianas (p. 297). 
historia profana, que encuentra en ella significado y justificación. Además, esboza la relación entre presente histórico y cumplimiento escatológico en términos de escatología iniciada, en cuanto que el fin de la historia se ha iniciado en el acontecimiento de Cristo y en la acción sacramental de la Iglesia (Gibellini, 1998, p. 279).

El redescubrimiento de la esperanza como principio teológico se da gracias a Jürgen Moltmann y su obra Teología de la esperanza (1964). Este libro asume la realidad de la historia y el futuro del ser humano desde la óptica de la fe. La esperanza se convierte así en la puerta de entrada para acceder al misterio de Dios a través de la Resurrección de Jesús. El futuro de Dios desde la esperanza recae en el hombre como constructor de un presente feliz. Moltmann establece una tríada por medio de la cual el hombre queda abierto a Dios, "el principio teológico del primado de la esperanza, una cristología escatológica y una eclesiología mesiánica” (Gibellini, 1998, p. 300).

Por otra parte, toda esta reelaboración que acontece con fuerza nueva va abriendo el camino para que el acontecimiento más grande de la Iglesia del siglo XX, el Concilio Vaticano II, permita generar un auténtico vuelco en la reflexión teológica. Por consiguiente,

La teología del siglo XX, tal como se venía dando por estos tiempos, era muy rica, se venía desarrollando con mucha creatividad sobre todo en ciertos ambientes, principalmente europeos. Una intensa actividad teológica se desarrollaba en efecto en Alemania y Francia, pero también en otros ambientes como el de Bélgica y los Países Bajos. Era sobre todo de estos centros desde donde irradiaba en toda la Iglesia un gran influjo teológico renovador (Ramírez, 2012, p. 101).

Con base en lo anterior, a partir del Concilio Vaticano II se da en la Iglesia un giro en la comprensión de la teología, se pasa de un modelo fijo y estático, a un modelo más dinámico, encarnado, que piensa no desde un abstracto, sino desde la realidad. Dentro de este nuevo modelo de pensar y hacer teología, surgen dos documentos que impulsan la renovación de la Escatología en el siglo XX: Lumen Gentium y Gaudium Et Spes. Ambos van a poner el acento escatológico vivido y pensado en la realidad del mundo 
y de la Iglesia como sacramento de Cristo. De esta manera, la Escatología no se entiende inicialmente como un discurso sobre las cosas que pasarán al final de la historia, sino como la realidad operante de la esperanza que se vive y se profesa en el presente de la realidad del mundo y de la Iglesia, y que tendrá su cumplimiento-plenitud, eso sí, en Dios mismo.

La novedad que plantean estos documentos conciliares llega a América Latina y son recepcionados por la Conferencia Episcopal de Medellín, la cual brinda una mirada nueva de la Escatología, posibilitándole a ésta proponerse como "realidad encarnada", vinculada directamente con la historia, que parte de las situaciones presentes, concretas y puntuales de la vida humana, otorgando así una mirada de esperanza y transformación intrahistórica. La Escatología, a partir de aquí, se verá desde la óptica de la Encarnación, la cual puede brindar a los hombres y mujeres del presente una auténtica liberación.

Escatología, Pascua y Encarnación son un trinomio indivisible en términos de nuestro planteamiento, que busca re-descubrir la posibilidad para que la primera pueda tener una incidencia mayor en la vida de las personas de esta hora de la historia. Así pues, atreverse a comprender la realidad escatológica no sólo desde el "mito final" que ofrece la Pascua de Jesucristo, sino desde la "realidad encarnada", a fin de que la contribución de la teología Latinoamericana, a partir de Medellín, muestre su fuerza transformadora y liberadora, es una novedad que permite la captación de esta Conferencia.

Medellín marcó un hito en la reflexión eclesial, tanto Latinoamericana como mundial. Cabe la pregunta ¿Por qué Medellín marcó un hito en Latinoamérica? Por su revolución. Y con ello se entiende la capacidad de jugarse una nueva teología, una nueva cristología, una nueva Escatología. Medellín no es "grande" solo por sus temas y su manera de abordarlos, Medellín es grande por su espíritu. Lo renovable hoy sería eso: el espíritu original del cual brotó su manera de comprender la teología y con ello la Escatología.

Respecto a lo anterior, Medellín atina en una hermenéutica de la cultura. La hermenéutica que nace como interpretación de textos, pasó 
en la modernidad a interpretar hechos, acontecimientos. Por eso el ser humano puede hacer hermenéutica de hechos. Medellín logró interpretar el Concilio, a saber,

Se ha dicho repetidas veces, con razón, que la recepción del Concilio realizada por la Conferencia de Medellín fue una recepción original. Fue ciertamente la recepción de toda la inspiración y de todas las orientaciones conciliares en el sentido de la renovación eclesial, lo que tenía como objetivo el aggiornamento de nuestras Iglesias en sus estructuras y en lo referente a la concepción evangélica de todas nuestras realidades eclesiales. Pero fue sobre todo el interés por el tema de la misión pastoral de la Iglesia, entendida en el sentido de una diaconía histórica capaz de dar respuesta a los grandes problemas del mundo, de nuestros países, capaz sobre todo de inspirar toda la labor de construcción de nuestras sociedades con un sentido humano profundo, fraternal y social, lo que marcó el sentido de la Conferencia (Ramírez, 2008, p. 240).

Pero más allá, Medellín supo leer la vida y la historia y descubrir a Dios en ellas actuando como don salvífico y liberador para su pueblo. Que es uno de los ejes de la teología veterotestamentaria y fue el clamor de la Gaudium Et Spes, el documento más citado en Medellín:

Para cumplir esta misión es deber permanente de la Iglesia escrutar a fondo los signos de la época e interpretarlos a la luz del Evangelio, de forma que, acomodándose a cada generación, pueda la Iglesia responder a los perennes interrogantes de la humanidad sobre el sentido de la vida presente y de la vida futura y sobre la mutua relación de ambas. Es necesario por ello conocer y comprender el mundo en que vivimos, sus esperanzas, sus aspiraciones y el sesgo dramático que con frecuencia le caracteriza (4).

Medellín relee con libertad la cristología y el misterio de Dios, y haciendo esta relectura capta una nueva manera de comprender la Escatología. Medellín se deja sorprender por Dios; Medellín redescubre a Dios salvando y liberando en la historia humana. En Medellín hay una Escatología que se dimensiona a partir del hombre y de la vida, como únicos lugares de salvación. 
Hacer una hermenéutica de la Escatología a partir de la historia posibilita una dinámica nueva a la existencia humana. Es el propósito de este texto. Gracias a la nueva lectura teológica que procuró Medellín, la Escatología no es un conjunto de verdades abstractas que se establecerán al final de la historia, sino todo el acontecer salvífico de Dios desplegado en la Encarnación. Medellín regaló la posibilidad de saber que no esperamos la Escatología como un más allá metahistórico, sino que está aconteciendo desde las entrańas del mundo, saturando a todos de futuro en el más acá.

\section{La conferencia de Medellín como acontecer escatológico}

Introducción al documento

"Como cristianos, creemos que esta etapa histórica de América Latina está vinculada intimamente a la Historia de la Salvación".

\section{Mensaje final a los pueblos de América Latina}

Medellín se ha leído desde muchos ángulos y su novedad sigue siendo vigente en el contexto actual de la teología no sólo Latinoamericana, sino mundial. La palabra profética contenida allí ilumina con vehemencia los avatares sociales a los cuales el mundo está sujeto hoy. Su actualidad se establece porque se atrevió a pensar la teología no desde la metafísica, sino desde la historia. Es precisamente en esta historia, la cual es lugar teológico de la revelación de Dios, que se comparte y se construye en plural, desde la cual tiene toda su hondura poder hablar de Escatología. La historia revela a Dios, allí acontece, es escenario salvífico.

La Conferencia de Medellín abrió un panorama de autocomprensión, es decir, entendió la fe profesada en la Iglesia no desde presupuestos estáticos y ahistóricos, sino desde la realidad dinámica a la cual hay que darle una respuesta eficaz. Por lo tanto, al leer a Medellín desde la óptica Escatológica se entra en una relectura necesaria de los presupuestos de este tratado que tercamente muchos han querido llevar fuera de la historia y sólo a un mito final. En palabras de Jürgen Moltmann: 
al final, el principio. La escatología se considera como la "doctrina acerca de los novísimos", es decir, "la doctrina acerca de las últimas cosas" o "del fin de las últimas cosas". Pensar así es pensar rectamente en sentido apocalíptico, pero no es entender la escatología en sentido cristiano. La escatología tendrá que ver siempre con el fin, con el último día, con la última palabra, con la última acción: Dios es quien tiene siempre la última palabra. Pero si la escatología fuera esto y sólo esto, entonces sería preferible dejarla a un lado, porque las "últimas cosas" echan a perder el gusto por las "penúltimas cosas" (2004, p. 13).

La Escatología en Medellín inicia en la historia, retoma el gusto por las "penúltimas cosas". Vuelve a la realidad para redescubrir desde allí la revelación de Dios acontecida y donada al ser humano en el escenario común: la historia. Por lo tanto, "no basta por cierto reflexionar, logar mayor clarividencia y hablar; es menester obrar. No ha dejado de ser esta la hora de la palabra, pero se ha tornado, con dramática urgencia, la hora de la acción" (Celam, 1968, Introd, 3).

Con base en lo anterior, "el obrar" se entiende como manifestación auténtica de un existir en salida. Obrar y acción son las posibilidades reales de la salvación, es el paso de lo estático a la relación dinámica, paso de la especulación a la acción que se torna existencia donada, existencia salvífica. Dios acontece en la historia y a partir de la historia (Encarnación), deja de ser idea y concepto y se esclarece en relación fenomenológica de un existir con los otros. Es lo que Moltmann llama "la venida de Dios", en definitiva, Escatología.

El documento conclusivo de Medellín apuntala su reflexión en términos de praxis vital. El criterio de la historia tiene su síntesis en el ser humano capaz de transformación, la fe deja de ser repetición mecánica de conceptos aprendidos y se vincula indisolublemente con la antropología, con la existencia. De esta manera, el ser humano capaz de alteridad, es el mismo capaz de Escatología. Medellín afirma,

No podemos, en efecto, los cristianos, dejar de presentir la presencia de Dios, que quiere salvar al hombre entero, alma y cuerpo. En el día definitivo de la salvación Dios resucitará también nuestros cuerpos, por cuya redención gemimos ahora, al tener las primicias del Espíritu. Dios ha 
resucitado a Cristo y, por consiguiente, a todos los que creen en Él. Cristo activamente presente en nuestra historia, anticipa su gesto escatológico no solo en el anhelo impaciente del hombre por su total redención, sino también en aquellas conquistas que, como signos pronosticadores, va logrando el hombre a través de una actividad realizada en el amor (Celam, 1968, Introd, 5).

El Dios que se dona en la revelación tiene como criterio máximo salvar al ser humano de manera integral (Dei Verbum \#2). En la realidad antropológica reside el esjaton capaz de trastocar los esquemas de muerte que oscurecen la identidad originaria de relación. El "Cristo activamente presente en la historia” no es especulación de la salvación, sino y, ante todo, acción concreta de Dios, salida de sí que establece una alteridad consecuente desde la identidad vivida en plural. Así pues, la historia asumida por el hombre narra y hace visible la efectividad de la salvación de Dios. Historia, hombre y salvación, son realidades complementarias, no antagónicas. En esta triada la Conferencia de Medellín establece las bases de la Escatología.

Dentro de este horizonte de comprensión escatológico que propone Medellín, se inicia la deconstrucción de este tratado teológico. Se pasa del dogmatismo frío y rígido, propio de la teología escolástica, al movimiento intrahistórico en una vinculación práxica-existencial, la cual pondera el protagonismo del ser humano como receptor y destinatario de la salvación. De esta manera,

así como Israel, el primer Pueblo, experimentaba la presencia de Dios cuando lo liberaba de la opresión de Egipto, cuando lo hacía pasar el mar y lo conducía hacia la tierra de la promesa, así también nosotros, nuevo Pueblo de Dios, no podemos dejar de sentir su paso que salva, cuando se da el verdadero desarrollo, que es el paso, para cada uno y para todos, de condiciones de vida menos humanas, a condiciones más humanas (Celam, 1968, Introd, 6).

Con base en lo anterior, la salvación y la liberación de la cual habla Medellín, que no es otra que la misma propuesta en el Evangelio (Cfr. Juan 1, 1.14), tiene como escenario la historia humana. En ella radica la posibilidad de la tragedia y la frustración y, al mismo tiempo, la salvación en términos de desarrollo. Medellín le permitió al ser humano del siglo 
XX, y ahora al del XXI, acceder a Dios en un terreno común. Dios es de la historia, pertenece a ella, al mundo, a todo lo humano.

El principio Encarnación permite dimensionar la capacidad que tuvo Medellín para resituar a Dios en el mundo. Adentrarlo en las posibilidades cognoscibles del ser humano, rompiendo con las distancias metahistóricas propias de la escolástica y la neoescolástica. La Escatología de Medellín es un "in crecendo" desde la realidad de la historia humana atravesada por sus luces y sombras. El auténtico desarrollo del que habla Medellín tiene como centro al ser humano integral. La síntesis de la Escatología tiene su lugar en el hombre entendido de nuevo desde la Encarnación y la Pascua de Jesús.

Esta Escatología rompe el paradigma tradicional, abandona las posibilidades de mundos futuristas al margen de la "economía de la salvación", la cual implica seriamente asumir mundo, hombre y realidad. Hablar y reflexionar sobre la salvación prescindiendo de ello, es seguir haciendo demagogia homilética dando al ser humano opio de cielo, es desechar el más acá por el más allá. Medellín renovó la comprensión de la Escatología cristiana en términos de alteridad constructiva en la historia, la cual genera esperanza como principio de liberación integral.

\section{Promoción humana}

Este primer núcleo temático tiene como grandes temas de reflexión: Justicia, Paz, Familia y Demografía, Educación, Juventud. En ellos hay una palabra que vincula estas realidades al tema de reflexión que es la Escatología, se puede evidenciar que la realidad latente de la salvación está implícita como posibilidad real en el mundo a partir de ellos.

La Escatología tiene su referente directo en la historia. A partir de la Encarnación la complejidad del mundo queda asumida en la realidad de Dios. El Dios que revela Jesús parte de la vida misma del hombre, aquí está el punto de anclaje antropológico que permite captar a Dios en todo lo humano. Esta perspectiva total la entiende Medellín mirando la realidad dolorosa del pueblo Latinoamericano, es decir, "existen muchos estudios sobre la situación del hombre latinoamericano. En todos ellos se describe la miseria que margina a grandes grupos humanos. Esa miseria, como hecho colectivo, es una injusticia que clama al cielo" (Celam, 1968, I-1). 
Esta injusticia tiene rostro propio, la padece un ser humano concreto, no es un imaginario, no es un abstracto. El ser humano de América Latina tiene crisis de esperanza, lo cual impide la concreción existencial de la Escatología para que se vuelva modo de existencia capaz de transformación. Este es el inicio de la frustración y la angustia existencial, la cual desemboca en "cultura de muerte", como la llama el Papa Francisco. Cuando el Evangelio se vuelve palabra anestésica para el ser humano, las consecuencias son nefastas para la sociedad. No hay espacio para la esperanza como principio real de la Escatología, las condiciones sociales, políticas, culturales, no son capaces de generar un futuro distinto. ${ }^{5} \mathrm{El}$ ser humano queda atrapado en un eterno retorno de alienaciones.

Como se dijo anteriormente, es el ser humano concreto el destinatario del proyecto transformador de Dios, Dios no acontece sin más, es ante todo una realidad dialógica que implica reconocimiento y apertura. Esta salida hacia el otro, permite entender una Escatología puesta a la orden del día, es decir, justificada en la historia que necesita ser transformada. Dicho lo anterior,

Por eso, para nuestra verdadera liberación, todos los hombres necesitamos una verdadera conversión a fin de que llegue a nosotros el "Reino de justicia, de amor y de paz". El origen de todo menosprecio del hombre, de toda injusticia, debe ser buscado en el desequilibrio interior de la libertad humana, que necesitará siempre, en la historia, una permanente labor de rectificación. La originalidad del mensaje cristiano no consiste directamente en la afirmación de la necesidad de un cambio de estructuras, sino en la insistencia en la conversión del hombre, que exige luego este

5 Un análisis sintético de la situación social de la década del sesenta lo hace Álvaro Cadavid. (2010). En su libro: El camino pastoral de la Iglesia en América Latina y el Caribe. Bogotá: San Pablo. Dice así: a mediados de la década de los ańos sesenta, la situación social se resquebrajó aún más. La pobreza alcanzaba niveles insospechados, la violencia arreciaba, los regímenes militares se sucedían uno tras otro. Fracasaba la Alianza para el Progreso, las teorías desarrollistas caducaban, y comenzaba a abrirse paso a la teoría de la dependencia, a la cual se adherían la mayoría de los intelectuales y universitarios. Muchos de ellos se entregaron a las luchas, aún armadas, por la liberación. El triunfo de la revolución cubana y los diversos focos guerrilleros llevaron a prácticas políticas polarizadas, que, junto a regímenes dictatoriales, fundamentados en la ideología de seguridad nacional, fueron haciendo la situación muy tensa (p, 37). 
cambio. No tendremos un continente nuevo sin hombres nuevos, que a la luz del Evangelio sepan ser verdaderamente libres y responsables (Celam, 1968, I-3).

La salvación que se torna liberación parte del reconocimiento del ser humano íntegramente. Un ser humano auténtico con posibilidades de hacer el mal ${ }^{6}$, con inclinación a él (Cfr. Mateo 15, 10-20). Asumiendo esta realidad, la Escatología iniciada en el hombre, permitirá descubrir una ontología marcada por la trascendencia intrahistórica, que abre desde un panorama real, el advenimiento escatológico de Dios en la historia. No es la repetición mecánica de la fórmula tradicional para la parusía "el ya, pero todavía no", sino todo lo contrario, "el ya (plenitud), aconteciendo en el presente".

Respecto a lo anterior, la esperanza, columna vertebral de la Escatología, no es un quietismo antropológico (Cfr. Hechos 1, 6-11), sino toda una realidad dinámica que jalona la consumación en un proceso constante de evolución antropológica. Además, "la historia es vida vivida y reflexionada. Por consiguiente, viendo y viviendo la vida es como podremos descubrir el

6 Un excelente trabajo acerca de este tema es el libro de Andrés Torres Queiruga. (2011). Repensar el mal. Madrid: Trotta, 2011. Otro aporte en un nivel pastora está hecho por Carlos Mesters. (2009). En: Dios, ¿đónde estás? Una introducción práctica a la biblia. Navarra: Verbo Divino. En el capítulo 1, paraíso, ¿̇mito o realidad?, genera una lectura Latinoamericana de este pasaje bíblico, en correspondencia con las situaciones dolorosas en términos sociales de América Latina. También está el estudio reciente hecho por Adolfo Galeano (2017). En el libro: El drama histórico de la obra salvadora, una historia de gracia y de pecado: la soteriología cristiana. Bogotá: Universidad Pontificia Bolivariana - San Pablo. En el capítulo uno se hace una comprensión del mal como proceso antropológico plasmado en la historia, el cual ha acompañado la misma evolución humana desembocando en las estructuras (instituciones) de pecado.

7 Un estudio sistemático sobre este tema lo hace Juan José Alviar. (2011). En el libro Escatología. Eunsa: Navarra. Dice: el término parusía se utiliza de manera específica en el lenguaje cristiano, para expresar la venida gloriosa de Jesucristo al final de la historia. El vocablo deriva de pareimi (estar presente), palabra utilizada en el antiguo mundo helénico para referirse a la visita de personajes de la realeza o de seres divinos. Se emplea para expresar, en primer lugar, la presencia y, por derivación, el acto de venir de un personaje importante, trayendo consigo bines e inaugurando una nueva era para el pueblo (p, 51). 
futuro de la vida” (Boff, 2011, p. 17). No es esperar lo que viene, sino vivir existencialmente en el presente lo que será y que se tiene como realidad (don). Liberación y salvación tienen una profunda implicación antropológica que trasciende al hecho social.

La eficacia real de la Escatología propuesta por Medellín es devolver la liberación-salvación al plano del ser humano. Esta realidad que el documento llama "pecado" superada por la "conversión", en palabras de Gustavo Baena es lo siguiente:

El pecado, en singular, es algo que todos los seres humanos tenemos por ser limitados. Lo que Dios anda buscando es liberarnos de esa finitud, romper esa finitud y volvernos infinitos, como hizo con el caso Jesús. $\mathrm{O}$ sea que salvar a un ser humano, es liberarlo de esa estrechez de él mismo, auto-construyéndose con sus propios límites, para que sea capaz, por el poder de Dios y de Jesús resucitado, de romper esa finitud. El pecado sería que el hombre solamente se contentara con ser una criatura limitada en sí mismo. Pero Dios, al crearlo haciéndose implícito en él, lo que busca es romper con esa finitud (2017, p. 135).

La Escatología no hay que esperarla al final, sino dejarla acontecer en el presente. Medellín genera una nueva comprensión de este fenómeno poniéndolo directamente a dialogar con la realidad que necesita ser transformada. Dios vuelve a estar presente en medio del mundo como principio de esta transformación en una nueva antropología, desatada de los conceptos y puesta en el dinamismo de la historia creciente. La salvación y la liberación dejan de ser utopía ${ }^{8}$, ubican su lugar a partir del nuevo

8 Uno de los aportes amplios que se ha hecho sobre este tema es el estudio de Adolfo Galeano. (2015), en su libro: Visión cristiana de la historia, ensayo de escatología. Pontificia Universidad Javeriana - San Pablo: Bogotá. El capítulo V muestra como en el siglo XX fracasaron todas las utopías de la modernidad. Dice el padre Adolfo: el siglo XX experimentó uno de los choques más brutales y violentos del cristianismo con la ideología, al de la modernidad. Aquí saltaron en pedazos la idea de progreso de la modernidad y sus utopías, en las que había sido secularizado en esjaton cristiano y se hizo patente la advertencia de Pascal: "las invenciones de los hombres van avanzando de siglo en siglo. La bondad y la maldad del mundo son, en general, las mismas" ( $\mathrm{p}, 65)$. 
hombre, no como concepto, sino como realidad dinámica que se construye en plural. Así pues, Escatología y antropología se reclaman y se identifican, coexisten aconteciendo en el presente generando alteridad, por lo tanto,

El ser humano no está hecho para él mismo, sino que está hecho para los demás. De modo que lo que Dios hace al romper la finitud, es hacer que se trascienda él mismo, particularmente en sus hermanos, los seres humanos. O sea, salvar a un ser humano, es volverlo disponible para que él, libremente, se entregue con su libertad en función de los otros. Esa es la esencia de la salvación (Baena, 2017, p. 136).

Buena parte del tiempo, la Escatología se dedicó a la especulación sobre el más allá. En función de esta orientación limitada, se han justificado toda clase de usos y abusos, de manera especial, los relatos bíblicos que tocan temas escatológicos. A propósito de esto, Andrés Torres Queiruga dice lo siguiente,

Roto el tabú literalista, resulta claro que, cuando la Escritura habla de las postrimerías, sus proposiciones no pueden ser tomadas como una descripción objetiva el más allá. Cuanto al respecto se dice, remite a un ámbito que, por definición, es radicalmente distinto de este mundo en el que se desenvuelven nuestra vida y nuestra historia, y que, por lo tanto, rompe todos los esquemas, resultando de todo punto inobjetivable. Las afirmaciones de la revelación no tienen por objeto aumentar nuestros conocimientos, como si se tratase de una especie de geografía ultraterrena o de una crónica de lo

9 El tema de la revelación, sobre todo la manera en que a partir del siglo XX se ha venido entendiendo, permite ampliar las categorías teológicas para una actualización más coherente con la realidad dinámica de la historia de la salvación. Rompiendo con el dictado divino y proponiendo una realidad dialógica en términos de autodonación, es la propuesta de la teología fundamental a partir de la Dei Verbum. En este horizonte de nueva comprensión se inscriben obras como Ramírez, A. (2013). Cuestiones de teología fundamental, revelación y fe. Medellín: Universidad Pontificia Bolivariana; Baena, G. (2014). Fenomenología de la Revelación. Teología de la biblia y hermenéutica. Navarra: Verbo Divino; Latourelle, R. (2016). Teología de la Revelación. Salamanca: Sígueme. Torres Queiruga, A. (2008). Repensar la revelación. Madrid: Trotta. 
que sucederá después de la muerte. Lo que allí se dice quiere, ante todo y sobre todo, iluminar nuestra vida actual (1995, p. 19-20).

Con base en lo anterior, Medellín centra la Escatología en la historia como escenario protagónico del acontecimiento salvífico de Dios, se aparta de la especulación arbitraria sobre el más allá, abriendo paso a la cercanía intrahistórica del fenómeno salvífico en términos de liberación integral, de esta manera, "en la Historia de la Salvación la obra divina es una acción de liberación integral y de promoción del hombre en toda su dimensión, que tiene como único móvil el amor" (Celam, 1968, I-4). La salvación que se pregona como realidad donada de Dios, siempre tiene implicaciones históricas y antropológicas concretas. Es el camino seguido por Medellín, devolver a la historia la Escatología procesual que la especulación le había arrebatado.

El compromiso histórico y existencial son ineludibles para la fe. La pretensión del fideísmo desencarnado, es la expresión máxima de una apología antiteológica por seguir fundamentando a Dios fuera del mundo. En cuanto a lo anterior,

Ciertamente para la Iglesia, la plenitud y la perfección de la vocación humana se logran con la inserción definitiva de cada hombre en la Pascua o triunfo de Cristo, pero la esperanza de tal realización consumada, antes de adormecer debe "avivar la preocupación de perfeccionar esta tierra, donde crece el cuerpo de la nueva familia humana, el cual puede de alguna manera anticipar un vislumbro del siglo nuevo". No confundimos progreso temporal y Reino de Cristo; sin embargo, el primero, "en cuanto puede contribuir a ordenar mejor la sociedad humana, interesa en gran medida al Reino de Dios (Celam, 1968, I-5).

La historia camina hacia la consumación plena y definitiva que ha garantizado la Pascua de Jesús. El final especulado por muchos se hace visible en la economía salvífica (Encarnación y Pascua). Desde estas dos realidades Dios queda abierto totalmente para el ser humano, permitiendo vivir la existencia no desde la incertidumbre, sino desde la certidumbre de la donación total de Dios en Jesús. Esta percepción la entiende un místico como Juan de la Cruz, al escribir, 
Si te tengo ya habladas todas las cosas en mi Palabra, que es mi Hijo, y no tengo otra, ¿qué te puedo yo ahora responder o revelar que sea más que eso? Pon los ojos en él, porque en él te lo tengo dicho todo y revelado, y hallarás en él aún más de lo que pides y deseas. Porque tú pides locuciones y revelaciones en parte, y sí pones en él los ojos, lo hallarás en todo; porque él es toda mi locución y respuesta y es toda mi visión y toda mi revelación. Lo cual os he ya hablado, respondido, manifestado y revelado, dándoosle por hermano, compañero y maestro, precio y premio (Subida al Monte Carmelo, 2, 22).

La Escatología no es un misterioso descubrimiento de realidades más allá de la historia, ni una palabra demagógica sobre lo que hay después de la muerte. En el acontecimiento Jesús, la Escatología ha tomado un rumbo histórico, que le permite al ser humano comprender el dinamismo de su existencia en clave de futuro. A partir de Jesús, la historia ha quedado saturada de eternidad. La Escatología no nos espera, la Escatología está aconteciendo en el presente de la realidad. La palabra escatológica es el Hijo, en Él Dios ha vaciado todo su futuro salvífico. Esta dimensión de la Escatología que acontece la comprende Medellín al decir,

En la búsqueda de la salvación debemos evitar el dualismo que separa las tareas temporales de la santificación. A pesar de que estamos rodeados de imperfección, somos hombres de esperanza. Creemos que el amor a Cristo y a nuestros hermanos será no solo la gran fuerza liberadora de la injusticia y la opresión, sino la inspiradora de la justicia social, entendida como concepción de vida y como impulso hacia el desarrollo integral de nuestros pueblos (Celam, 1968, I-5).

Ante los optimismos que se tornan ideología como hechura humana, la realidad escatológica se funda en la esperanza como don de Dios. De esta manera, la Conferencia de Medellín establece el criterio para dimensionar en la historia del ser humano el acontecer de Dios. Asumir con principio de realidad todo lo que se teje en los pueblos Latinoamericanos, es la verdadera esperanza. Un proceso de autoimplicación que englobando la realidad despliega la transformación a partir del compromiso evangélico. En palabras de Joseph Moingt, 
La escatología no consiste, por tanto, en decir: no viváis para el mundo: porque tiene un fin. Sino más bien: no viváis para poseer el mundo y dilapidarlo, sino vivid intensamente para convertirlo en un reino de justicia y de amor, pues lo encontraréis después de vuestra muerte tal como hayáis intentado construirlo para los otros; no os dejéis absorber, pues por las cosas, por el egoísmo, por el dinero; comenzad a vivir desde ahora una vida de relación, porque esa será también la verdadera vida que os espera (2017, p. 250).

Medellín apuesta por entender de una manera más real la palabra "otro". Parte del reconocimiento de su identidad como persona y sobre todo de su rostro que cuenta una historia única. Este es un llamado urgente que le hace a lo que se sigue sosteniendo hoy como Jerarquía, dice,

El sentido de servicio y realismo exige de la Jerarquía de hoy una mayor sensibilidad y objetividad sociales. Para ello, hace falta el contacto directo con los distintos grupos socio-profesionales, en encuentros que proporcionen a todos una visión más completa de la dinámica social (Celam, 1968, I-18).

Realidad e Iglesia ${ }^{10}$ no pueden ser fenómenos antagónicos, no pueden seguir excomulgándose mutuamente bajo la pretensión de absolutismos que generan antihumanismos. Este esfuerzo de conjunto, no sólo para la Jerarquía, sino para todos los discípulos de Jesús en esta hora de la historia, implica una desestructuralización de la comprensión de mundo y de Iglesia, para volver a poner en el centro al ser humano con rostro propio. Este camino

10 El magisterio del Papa Francisco ha sido una constante llamada al encuentro cercano, libre y desprevenido con la realidad. Este es el camino de la implicación que permite un contacto directo con el mundo que se habita. La Exhortación Apostólica Evangelii Gaudium (2013), es toda una propuesta de salida y de conocimiento de los fenómenos que se tornan desafíos en el siglo XXI. Dice: como consecuencia, la Iglesia sabe involucrarse. Jesús lavó los pies a sus discípulos. El Señor se involucra e involucra a los suyos, poniéndose de rodillas ante los demás para lavarlos. La comunidad evangelizadora se mete con obras y gestos en la vida cotidiana de los demás, achica distancias, se abaja hasta la humillación si es necesario, y asume la vida humana, tocando la carne sufriente de Cristo en el pueblo (p, 22). 
abierto por Medellín lleva a la implicación existencial, a reconocer al otro como un legítimo otro en su realidad genuina, de esta manera,

Con la mirada y los sentimientos de Jesús, que contempla la realidad no como juez, sino como buen samaritano; que reconoce los valores del pueblo con el que camina, así como sus heridas y pecados; que descubre el sufrimiento callado y se conmueve ante las necesidades de las personas, sobre todo cuando estas se ven avasalladas por la injusticia, la pobreza indigna, la indiferencia, o por la perversa acción de la corrupción y la violencia (Francisco, 2017, p. 109).

Las implicaciones sociales dentro de este marco de comprensión de la fe cristiana propuesta por Medellín son innegables. Una de las realidades que genera esta perspectiva desde la realidad, es la paz. En el Evangelio, uno de los presupuestos escatológicos que vincula una nueva experiencia es la paz como signo del Resucitado (Cfr. Mt 28, 5-10; Mc 16, 6; Lc 24, 36; Jn 20, 19-29), la cual implica una realidad nueva impulsada por Dios en Jesús a partir de su existencia Pascual. El compromiso social de la Paz genera un estilo nuevo de vida, uno que abre espacios para erradicar la frustración del ser humano ante la amenazante muerte. Medellín capta esta orientación evangélica en términos de transformación, la cual se inserta dentro del cambio evolutivo propio de la realidad humana. Esta construcción de la paz acentúa la dimensión histórica de la Escatología propuesta por la Conferencia, pues es un "ir hacia", no un mantener perpetuo que frustra la esperanza como criterio humanizador, dice,

La paz solo se obtiene creando un orden nuevo que comporta una justicia más perfecta entre los hombres. En este sentido, el desarrollo integral del hombre, el paso de condiciones menos humanas a condiciones más humanas, es el nombre nuevo de la paz. La paz, en segundo lugar, es un quehacer permanente. La comunicad humana se realiza en el tiempo y está sujeta a un movimiento que implica constantemente cambio de estructuras, transformación de actitudes, conversión de corazón (Celam, 1968, II-14).

Ahora bien, la paz, entendida como una nueva manera de ser persona, lleva a replantear el sentido de la educación, ¿se educa para qué? El ser humano está en constante búsqueda, del por qué natural que brota de 
su interior ante el mundo, se forma la manera de captar y apropiarse de la realidad que habita. La educación que no proporcione esperanza es un cúmulo hueco de datos y cifras que no transforman la vida en existencia consciente. Medellín redimensiona la educación, la lleva a una altura capaz de hacer nuevas personas en un presente cuajado de futuro que lleva a impactar todo el tejido social. Así pues,

La educación Latinoamericana en una palabra está llamada a dar una respuesta al reto del presente y del futuro, para nuestro continente. Solo así será capaz de liberar a nuestros hombres de las servidumbres culturales, económicas y políticas que se oponen a nuestro desarrollo. Cuando hablamos así no perdemos de vista la dimensión sobrenatural que se inscribe en el mismo desarrollo, el cual condiciona la plenitud de la vida cristiana (Celam, 1968, IV-7).

La educación centrada en la historia real, aquella que desborda los idealismos y pone de frente al ser humano ante su mundo necesitado, permite pasar del concepto a la acción. La liberación se hace efectiva a través de la educación ${ }^{11}$ ya que es capaz de recrear la antropología en la cual se establece la Escatología como realidad intrahistórica. Educación para la esperanza, educación como proceso dinámico escatológico, que lleva al ser humano a transformar la realidad descubriendo en ella su dimensión sobrenatural.

Una educación integral, que sea capaz de darle al ser humano la trascendencia real para sumergirse en su historia y transformarla. El obrar

11 Este tema ha sido ampliamente trabajado por Paulo Freire. Su vasta obra sobre pedagogía crítica o pedagogía de la liberación, le ofrece a la persona un proceso de humanización desde su propia realidad, asumiendo su entorno en un proceso de transformación, permite generar una esperanza práctica un nuevo entorno. Destaco dos obras: la educación como práctica de la libertad (1967) y pedagogía del oprimido (1985).

Otro de los autores que permite un recorrido amplio a través del tema de la liberación es Enrique Dussel. Su libro filosofía de la liberación (2011), es una obra a través de la cual se puede concretar el tema desde la realidad antropológica Latinoamericana, que permite ver más allá y comprender los avatares que han acompañado las realidades de estos pueblos y su proceso liberacionista. 
escatológico está implícito en la realidad humana a través de la Encarnación y la Pascua, es así como la fe se va convirtiendo en la pedagogía antropológica capaz de parir una realidad nueva (Cfr. Romanos 8, 22-25) que implica al ser humano total. En consecuencia,

Toda liberación es ya un anticipo de la plena redención de Cristo, la Iglesia de América Latina se siente particularmente solidaria con todo esfuerzo educativo tendiente a liberar a nuestros pueblos. Cristo pascual, imagen del Dios invisible, es la meta que el designio de Dios establece al desarrollo del hombre, para que alcancemos todos la estatura del hombre perfecto (Celam, 1968, IV-9).

Una educación liberadora rompe con el determinismo histórico creado por muchos para satisfacer ideologías fatalistas y abrumadoras, que hacen del ser humano un instrumento vulgar de sacrificio. La educación auténtica genera esperanza, no un simple pensamiento positivo, sino esperanza como criterio definitivo de la persona que la impulsa a actuar en favor de una realidad social plural e inclusiva. Escatología y pedagogía son dos caminos que se abren desde América Latina a partir de la historia, la cual es común a todos, y desde la cual el ser humano pude tener una amplia posibilidad de encarnar en sí la realidad, para ver en ella el plus trascendente que la sustenta.

La culminación de este primer núcleo temático tiene una palabra para la juventud, la cual se convierte en base fundamental para la constante renovación de la fe eclesial. Las nuevas voces que con agudo sentido son capaces de apuntar a las necesidades de la sociedad, permiten descubrir todo el potencial que se encierra en la existencia humana para una auténtica transformación desde la praxis. Conforme a esta idea, Medellín expresa,

Ve en efecto en la juventud el renovado comienzo y la persistencia de la vida, o sea, una forma de superación de la muerte. Esto no tiene solo un sentido biológico, sino también socio-cultural, sicológico y espiritual. En efecto, frente a las culturas que muestran signos de vejez y caducidad, la juventud está llamada a aportar una revitalización; a mantener una fe en la vida, a conservar su facultad de alegarse con lo que comienza. Ella tiene la tarea de reintroducir permanentemente el sentido de la vida. Renovar las culturas y el espíritu, significa aportar y mantener vivos nuestros sentidos 
de la existencia. La juventud está, pues, llamada a ser como una perenne reactualización de la vida (Celam, 1968, V-11).

La juventud se convierte en signo escatológico de la realidad eclesial, pues a partir de ella la existencia se mira con una renovada decisión, capaz de trascender la muerte. La fe como decisión existencial de vivir en la esperanza implica un modo de ser en el mundo, una manera de asumir la vida total insertada en la historia y la realidad como principios gestadores de sentido. La juventud tiene la capacidad de provocar en la sociedad miradas nuevas, las cuales se necesitan con urgencia en el presente histórico del mundo. Es así como Medellín va entendiendo el proceder escatológico de la fe cristiana, toda una realidad desbordada en el ser humano y en la historia de manera encarnada. La Escatología en el documento de Medellín queda abierta a todos, pues interpreta la acción salvadora de Dios leyendo el mundo en el cual se va dando la Palabra hecha realidad. En definitiva, "la fe es la interpretación escatológica de la existencia, su sentido pascual, y por ello, la novedad que encierra el Evangelio. La fe, anuncio del nuevo sentido de las cosas, es la renovación y rejuvenecimiento de la humanidad" (Celam, 1968, V-12).

\section{Evangelización y crecimiento de la fe}

Este segundo núcleo temático de la Conferencia de Medellín, tiene por temas principales: Pastoral Popular, Pastoral de élites, Catequesis, Liturgia. En este ámbito de reflexión, el tema escatológico va tomando un matiz práctico al interior del quehacer eclesial, Medellín ofrece una visión pastoral sustentada por el impulso escatológico, el cual deja de ser discurso para establecerse como acontecer vital.

Medellín rompe con la repetición anacrónica de palabras y hechos, que sustentaron por mucho en la Iglesia una figura de tradición ${ }^{12}$ como

12 El Papa Benedicto XVI dedicó su audiencia general del miércoles 26 de abril del año 2006 al tema de la Tradición. Decía: La Tradición es el río vivo que se remonta a los orígenes, el río vivo en el que los orígenes están siempre presentes. El gran río que nos lleva al puerto de la eternidad. Y al ser así, en este río vivo se realiza siempre de nuevo la palabra del Señor que hemos escuchado al inicio de labios del lector: 
duplicación de lo antiguo en la realidad presente. Esta idea fatal que satura la acción dinámica del proceso evolutivo constante de la economía salvífica, se quiebra en Medellín, pues exige de la fe y de la Iglesia una renovada acción capaz de leer con ojos nuevos la sociedad que necesita una palabra distinta. Este impulso se evidencia cuando habla de la pastoral,

Hasta ahora se ha contado principalmente con una pastoral de conservación, basada en una sacramentalización con poco énfasis en una previa evangelización. Hoy, sin embargo, las mismas transformaciones del continente exigen una revisión de esa pastoral, a fin de que se adapte a la diversidad y pluralidad culturales del pueblo latinoamericano (Celam 1968, VI-1).

La "pastoral de conservación" es la idolatría del sí mismo que se establece a partir del miedo a lo nuevo y a lo distinto. Seguir en este esquema es dejar de lado la capacidad que ha tenido Medellín para "soltar las amarras" como diría Heidegger, de una estructura que no dejaba campo a la acción. El espíritu de la Conferencia ha volcado la manera de entender y hacer la pastoral, pues ha metido en la realidad de la vida a Dios. Así pues, la Escatología no queda como recurso último, o paliativo, para enfrentar la realidad exigente que sale al encuentro del ser humano, sino, que se torna experiencia cristiana genuina, modo de estar y habitar el mundo. La Escatología a partir de Medellín queda enraizada en la tierra.

El camino histórico del ser humano a partir de la fe, no es un trasegar mediado por el fatalismo que busca consuelos extraterrenos. Esta visión planteada por una teología de antaño, ha quedado superada por el realismo de Medellín, el cual redimensiona toda la historia desde una comprensión más amplia, la cual le permite al ser humano entenderse como lugar teológico en medio de la realidad. Así pues, "la fe, como acto de una humanidad

"He aquí que yo estoy con vosotros todos los días, hasta el fin del mundo" ( $M t$ 28, 20). La analogía del río que hace el Papa, permite redescubrir el valor de la palabra Tradición, que no es repetición, sino todo un caudal de vida nueva que es capaz de reinterpretar desde el presente la raíz original del mensaje siempre nuevo para el ser humano de todos los tiempos. 
peregrina en el tiempo, se ve mezclada en la imperfección de motivaciones mixtas" (Celam, 1968, VI-6). Esta conciencia de historia y de tiempo, es lo primero que otorgar la pastoral, pues a partir de ella el ser humano tiene la posibilidad de entenderse desde un origen encarnado.

Una pastoral escatológica abre un diálogo fecundo con la cultura a partir del ser humano. La pastoral como acontecer practico de la fe, es la palabra cultivada en la esperanza que nace y brota para ser entregada. De esta manera, "pertenece, pues, al acto de fe, bajo el impulso del Espíritu Santo, aquél dinamismo interior por el que tiende constantemente a perfeccionar el momento de apropiación salvífica convirtiendo en acto de donación y entrega absoluta de sí" (Celam, 1968, VI-7).

Solamente se hará creíble la Escatología asumiéndola en clave de donación. Dios, al donarse enteramente en la Encarnación, salva. Esta entrega de sí, este vaciamiento de sí, posibilita experimentar en la realidad lo que se tenía intuido para el final. A partir de la Encarnación se comprende que el atributo máximo de Dios es salir constantemente hacia el otro. La eternidad entra en la humanidad a través de un diálogo, pues a partir de un interlocutor Dios puede salvar.

La salvación es don y entrega, desde este ángulo el ser humano queda implicado en este movimiento por su capacidad de relación, es así como la Escatología cristiana deja de ser utopía y se convierte en relacionalidad. La entrega de sí mismo como salvación humanizadora, rompe con la metafísica que ubica a Dios ad extra. Es la Encarnación y no el mito final de un cielo desencarnado, lo que provoca salvación y liberación en la realidad. La historia evidencia la donación como fenómeno real, generando constantemente la entrega de sí mismo, esta entrega es la Escatología aconteciendo en el tiempo.

Esta comprensión de la Escatología que se basa en la practicidad como principio originario, le permite al ser humano desmontar el discurso que se ha hecho tradicionalmente sobre este tratado teológico. Uno de los elementos fundamentales de la Conferencia de Medellín es la seriedad con la que asume el tema comunitario, desde el cual la experiencia de la fe se enriquecerá y abrirá una vía hacia la existencia teológica, superando la conceptualización. Escatología y comunidad quedan implicadas, de manera que, 
Esta evangelización debe estar en relación con los signos de los tiempos. No puede ser atemporal ni ahistórica. En efecto, los signos de los tiempos que en nuestro continente se expresan sobretodo en el orden social, constituyen un lugar teológico e interpelaciones de Dios. La evangelización de que venimos hablando debe explicar los valores de justicia y fraternidad, contenidos en las aspiraciones de nuestros pueblos, en una perspectiva escatológica (Celam, 1968, VII-13).

Medellín se establece en la misma línea que proporciona el Concilio Vaticano II, respecto a la Escatología, el capítulo VII de la Lumen Gentium, aporta una visión comunitaria de ésta. Esta base, es tomada por la Conferencia, pero llevada a una realidad concreta, es decir, establecer el carácter comunitario de la salvación en rostros concretos. Encarnar en el contexto (comunidad) la experiencia escatológica. La comunidad es la partera de la Escatología.

El trasegar de Medellín permite vislumbrar otra realidad teológica, una posible. Los estrechos límites de la reflexión pueden tener un asidero más amplio, aquél por el que Dios ha optado desde siempre, la historia, y que permite una armonía entre palabra y acción. Este constitutivo al que Medellín se aferra, permite entender dentro de la dinámica eclesial, la catequesis desde otras dimensiones, a saber,

Sin caer en confusiones o en identificaciones simplistas, se debe manifestar siempre la unidad profunda que existe entre el proyecto salvífico de Dios, realizado en Cristo, y las aspiraciones del hombre; entre la historia de la salvación y la historia humana; entre la Iglesia, Pueblo de Dios, y las comunidades temporales; entre la acción reveladora de Dios y la experiencia del hombre; entre los dones y carismas sobrenaturales y los valores humanos. Excluyendo así toda dicotomía o dualismo en el cristiano, la catequesis prepara la realización progresiva del Pueblo de Dios hacia su cumplimiento escatológico, que tiene ahora su expresión en la liturgia (Celam, 1968, VIII-4).

Medellín inicia el cierre en América Latina, de la brecha dualista que ha permeado la teología, realidad triste que sigue estando vigente hoy. Desde la postura planteada en la catequesis hay toda una renuncia a las posiciones 
separatistas entre historia y cielo, mundo y salvación. A partir de esta opción, la realidad catequética no será un aprendizaje forzado y repetitivo de fórmulas y dogmas, sino toda una experiencia de conciencia integral antropológica, en la cual Dios toma protagonismo en el hecho de su relación dialogal.

El cambio de lenguaje permite atisbar la centralidad radical de la revelación como acto de donación. La catequesis será entonces, la opción fundamental del ser humano por entrar y estar en relación, viviendo desde las posibilidades de su existencia la realización progresiva del acontecer escatológico. Por esto,

De acuerdo con esta teología de la revelación, la catequesis actual debe asumir totalmente las angustias y esperanzas del hombre de hoy, a fin de ofrecerle la posibilidad de una liberación plena, las riquezas de una salvación integral en Cristo, el Señor. Por ello debe ser fiel a la transmisión del Mensaje bíblico, no solamente en su contenido intelectual, sino también en su realidad vital encarnada en los hechos de la vida del hombre de hoy (Celam, 1968, VIII-6).

Al reenfocar el objetivo de la catequesis, Medellín abre un camino de inclusión social y existencial en la vida de las personas que escuchan el Evangelio. Una catequesis encarnada en el dramatismo de la vida de los pueblos de América Latina, permite entender a Dios como principio de realidad que posibilita actuación y cambio. La salvación esperada como último recurso deja de ser ilusión futurista y se convierte en presente continuo, hablar de liberación para el final o de liberación en otro mundo, es una bofetada vulgar al ser humano sufriente del presente, una burla que deshumaniza. Medellín abre el camino para descubrir a Dios actuando desde las entrañas del mundo, compartiendo toda la realidad con el hombre, más aún, posibilita la comprensión de Dios a partir del mismo ser humano existente.

Asumiendo la realidad a partir de la Encarnación, Dios queda totalmente implicado en ella, se une a ella hasta el extremo. Este es el camino de comprensión que hace consciente Medellín, y es aquí donde se vincula el hecho celebrativo, la realidad litúrgica. Se celebra lo donado y lo acontecido que opera activamente en la historia. Conforme a lo anterior, 
La presencia del Misterio de la Salvación, mientras la humanidad peregrina hacia su plena realización en la Parusía del Señor, culmina en la celebración de la liturgia eclesial. La liturgia es acción de Cristo cabeza y de su Cuerpo que es la Iglesia. Contiene, por tanto, la iniciativa salvadora que viene del Padre por el Verbo y en el Espíritu Santo, y la respuesta de la humanidad en los que se injertan por la fe y la caridad en el Cristo recapitulador de todas las cosas. Como quiera que no vivamos aún en la plenitud del Reino toda celebración litúrgica está esencialmente marcada por la tensión entre lo que ya es una realidad y lo que aún no se verifica plenamente, es imagen de la Iglesia a la vez santa y necesitada de purificación, tiene un sentido de gozo y una dolorosa conciencia de pecado. En una palabra, vive en la esperanza (Celam, 1968, IX-2).

La liturgia es la existencia del ser humano comprendida desde la dimensión trascendente que se hace historia compartida y celebrada. El camino de la donación de Dios que se hace historia permite celebrar, no un acto, sino la vida real en la cual ha quedado implicado. En este proceso dialógico se puede entender la Escatología como realidad acontecida que desborda en la existencia del ser humano todo su actuar. La celebración litúrgica comprendida desde Medellín parte del realismo del mundo, no desde la incomprensión ultraterrena que vuelve la acción sacramental ritos mágicos. La Escatología se vive de manera especial en la liturgia, pues en ella encuentra los signos del mundo auténtico que asumidos desde la esperanza son transformados en el actuar del hombre mediante la fe.

\section{La Iglesia visible y sus estructuras}

El último núcleo temático de la Conferencia de Medellín, ofrece el siguiente abanico de reflexión: Movimientos de Laicos, Sacerdotes, Religiosos, Formación del clero, Pobreza de la Iglesia, Pastoral de conjunto, Medios de Comunicación Social. El tema escatológico ya ha quedado expuesto en las temáticas anteriores, no obstante, dentro de este segmento final se mantiene el hilo de reflexión planteado por la Conferencia, no renunciando a su dinamismo salvífico intrahistórico.

Una de las posibilidades amplias que otorgó Medellín fue la comprensión del papel del laico en la Iglesia, las palabras planteadas por 
la Lumen Gentium y la Gaudium et spes, fueron abriendo esta manera protagónica de ser Iglesia dentro de la realidad social. El laico no es una forma reducida de la existencia cristiana, o mucho menos, un peón dentro de una estructura piramidal. Estas comprensiones torcidas y macabras de Iglesia, corresponden a un anacronismo instalado para justificar poderes ambiguos que van en contravía del Evangelio de Jesús.

Los laicos, como base fuerte de la Iglesia ${ }^{13}$, permiten un acercamiento más próximo a realidades específicas. Es desde este horizonte donde el gran objetivo eclesial de la Lumen Gentium puede verse realizado, abandonar la idea de una estructura piramidal eclesial, que tanto daño hace, y pasar a la realidad dinámica de la comunión, donde se genere una sinergia evolutiva capaz de hacer presente el Reinado de Dios en el mundo. Medellín entiende que el camino de la Iglesia debe ser la comunidad, no la institución reforzada por conceptos anacrónicos.

Con base en lo anterior, se abre el camino para que los discípulos de Jesús en esta hora de la historia, puedan acceder todos juntos, desde sus opciones específicas, a una transformación antropológica y social que emana de una llamada intrahistórica que reclama un esfuerzo común. Así pues,

Por mediación de la conciencia, la fe, que opera por la caridad, está presente en el compromiso temporal del laico como motivación, iluminación y perspectiva escatológica que da su sentido integral a los valores de dignidad humana, unión fraterna y libertad que volveremos a encontrar limpios de toda mancha, iluminados y transfigurados en el Día del Señor. Enseña también la Iglesia que la esperanza escatológica no merma la importancia de las tareas temporales, sino que más bien proporciona nuevos motivos de apoyo para su ejercicio (Celam, 1968, X-10).

13 En este último tiempo, el Papa Francisco ha emprendido un camino que posibilita recomprender la figura del laico como agente protagónico de la praxis de la fe en la sociedad. Sus Exhortaciones Apostólicas Evangelii Gaudium (2013) y Gaudete Et Exsultate (2018), permiten vislumbrar con suma claridad, el papel transformador de la fe en medio de un mundo secularizado. 
La Escatología situada en la historia y en la realidad, permite asumir el mundo como escenario definitivo del Dios revelado. En esta coordenada el ser humano puede entender que la experiencia de Dios no aísla, sino que impulsa desde el mismo hombre procesos integrales de transformación "más humanos". Asumiendo de manera seria el compromiso que se tiene con la realidad, se podrán evidenciar los signos de liberación y salvación operados por Dios en una continuidad salvífica. Dentro del mundo inicia la constatación de la esperanza como don.

La orientación escatológica que propone Medellín no genera un estado de espera pasiva o de quietud antropológica, antes bien, impulsa desde la existencia de la fe un compromiso con la sociedad y la realidad. Es aquí donde el paradigma escatológico que se establece desde la fe para el mundo, tiene sus raíces hondas en el estatuto histórico de la salvación. La palabra de sentido que brota desde el acontecer de la fe no es ahistórica, si se renuncia a la construcción y transformación que jalona la esperanza esperando un cielo perfecto, la Escatología sería pura superstición mítica.

Esta realidad que propone Medellín, dando un vuelco total de la comprensión de la Escatología, toca de manera especial la vida religiosa. Una intelección actualizada de esta realidad eclesial, permitirá tener mayor eficacia en el proceso de transformación social y humano que exigen los actuales desafíos. Por lo tanto,

A lo largo de la historia de la Iglesia, la vida religiosa ha tenido siempre, y ahora con mayor razón, una misión profética: la de ser testimonio escatológico. Todo cristiano -sea religioso o laico- la de buscar el Reino de Dios, identificándose, por amor, con Cristo en el misterio de su Encarnación, Muerte y Resurrección, que culmina en la escatología. esta consagración peculiar es un compromiso a vivir con mayor intensidad el aspecto escatológico del cristianismo para ser dentro de la Iglesia, de un modo especial, "testigo de la ciudad de Dios" (Celam, 1968, XII-2).

La exigencia de las realidades nuevas, que hacen parte del dinamismo evolutivo de la construcción humana en el tiempo, no pueden ser indiferentes a la vida de la Iglesia en sus manifestaciones particulares, desde este ángulo surge una hermenéutica existencial capaz de una interpretación amplía, la cual permita una incidencia directa en la transformación del mundo. El 
fenómeno de la vida religiosa no es un arrebatamiento del mundo para vivir al margen de la vida real, la historia reclama la presencia de estos hombres y mujeres capaces de entender desde posiciones diversas el actuar de Dios en la realidad.

La opción de esta vida que marca particularidad, la cual hace presente la dimensión escatológica, no se debe entender como un exclusivismo que pone por encima de los otros al consagrado, sino, como la manifestación más clara de la conciencia que le permite habitar el mundo como don recibido. Aquí está el reto mayúsculo. En la manifestación del actuar de la vida religiosa, el amor que se torna entrega, la presencia encarnada de Dios despliega su acción como salida constante de Sí hacia los otros, hacia el ser humano. La Escatología se entiende no como un momento estático, sino como un dinamismo evolutivo engendrado en las entrañas de la historia que parte del hombre situado en la realidad.

La vida religiosa será un signo escatológico eficaz en la medida en que tenga la capacidad para comprender lo que el mundo necesita, es aquí donde inicia la efectividad de la salvación que se establece no como eternidad, sino como futuro. Esta dimensión queda abierta no como espera posmortem, sino desde la conciencia de presente que a partir de la fe posibilita un camino de transformación social y antropológico integral. El religioso y la religiosa son signo escatológico en la medida en que su existencia sea encarnada, es decir, vivan desde el futuro acontecido y donado por Dios a la humanidad, capaz de hacer visible en la historia los signos de la liberación para todos.

Finalmente, Medellín hace visible el mayor signo de la Escatología en la persona del pobre ${ }^{14}$. En el ser humano la fe cristiana se hace concreta,

14 El estudio de Federico Carrasquilla permite comprender ampliamente este concepto que ha sido abanderado en la teología Latinoamericana. En su obra: Escuchemos a los pobres. Aportes para una antropología del pobre (1996), hace un aporte antropológico que permite volver a la persona del pobre como otro, como sujeto, quitando el estigma social que pesa sobre él y abriendo un panorama de implicación que permite transformación integral.

Las obras de Gustavo Gutiérrez, Leonardo Boff, Jon Sobrino, Ignacio Ellacuría, permiten ver la realidad teológica ubicada en la vida y en los rostros de los pobres del continente. Este tema, que es existencia concreta de tantos, les permitió 
no es un imaginario, sino una realidad que permite entender de manera nueva las implicaciones antropológicas y sociales del Evangelio. La opción por los pobres, por los últimos de la sociedad humana, se convierte en el paradigma existencial de la opción que hace Dios en una constante salida de sí mismo. Aquí está la base fundamental de la salvación cristiana, el destinatario siempre es el otro con rostro y realidad.

Medellín recupera en tono de protesta la mínima cualidad de humanidad que debe brotar de la Iglesia: escuchar. La sordera social que invade la construcción de conglomerados de personas en los territorios Latinoamericanos, debe quedar fuera de la experiencia eclesial, afinar el oído y sintonizarlo con la vida del pobre es el principio de una hermenéutica teológica real y de una verdadera fe. Dicho esto, la Conferencia afirma: "un sordo clamor brota de millones de hombres, pidiendo a sus pastores una liberación que les llega de ninguna parte" (Celam, 1968, XIV-2).

El tema de la pobreza sobrepasa las esferas conceptuales a partir de Medellín, el discurso emotivo de rasgo evangélico cambia de orientación y se fundamenta a partir de la realidad y de la persona. A partir de este presupuesto la pobreza deja de ser tema a debatir y se convierte en prioridad para la Iglesia llamada a dar una respuesta acertada. Más aún,

la pobreza como carencia de los bienes de este mundo es, en cuanto tal, un mal. Los profetas la denuncian como contraria a la voluntad del Señor y las más de las veces como fruto de la injusticia y del pecado de los hombres (Celam, 1968, XIV-4).

Escuchar al pobre como sujeto real es entrar por el camino de una teología que se hace desde la tierra anclada en la realidad (Encarnada).

restructurar y dar un giro total al quehacer teológico de esta tierra. La teología a partir de Medellín, no vuelve a ser la misma, pues el imperativo categórico del servicio teológico, se establece desde abajo, desde el pobre como destinatario especial de la salvación histórica. Una mención especial merece el trabajo de Gustavo Gutiérrez en Mysterium Liberationis. Conceptos fundamentales de teología de la liberación. (1990). En el capítulo II del tomo I, hace una síntesis muy precisa de lo que se entiende por los pobres y la opción fundamental de la Iglesia de América Latina. 
Lo definitivo de la salvación que se ofrece desde el cristianismo no debe seguir siendo la sustentación anacrónica de unos postulados dogmáticos que rompen con la vida del ser humano, sino la eficacia de la Palabra escuchada que se traduce en una construcción antropológica y social en orden a la Escatología liberadora. En el pobre está la constante ratificación de la Escatología en la historia, él como sujeto histórico, permite romper con los idealismos teológicos y resituar la reflexión desde una epistemología existencial capaz de transformar la realidad.

El pobre desde la Conferencia de Medellín es lugar teológico de la salvación iniciada, pues en él queda abierto el camino a través del cual la eficacia salvífica despliega su acción intrahistóricamente. La Iglesia desde Medellín vuelve a su identidad profética que le permite legitimar su obra: servidora de la humanidad desde la persona concreta del pobre. Si la Iglesia Latinoamericana se entiende como portadora de la esperanza escatológica para el mundo, debe asumir lo que ella misma estableció en la Conferencia, a saber,

La pobreza como compromiso, que asume, voluntariamente y por amor, la condición de los necesitados de este mundo para testimoniar el mal que ella representa y la libertad espiritual frente a los bienes, sigue en esto el ejemplo de Cristo que hizo suyas todas las consecuencias de la condición pecadora de los hombres y que "siendo rico se hizo pobre", para salvarnos (Celam, 1968, XIV-4).

Toda esta comprensión eclesiológica que aporta Medellín pone en el centro al pobre como sacramento de Cristo, desde aquí la hermenéutica de la Iglesia pasa del dogma a la realidad, pues en la persona que habita el mundo latinoamericano con sus luces y sombras, se estructura una nueva manera de ser y hacer Iglesia, así pues,

Cristo nuestro salvador no sólo amó a los pobres, sino que "siendo rico se hizo pobre", vivió en la pobreza, centró su misión en el anuncio a los pobres de su liberación y fundó su Iglesia como signo de esa pobreza entre los hombres (Celam, 1968, XIV-7).

La Escatología parte del ser humano situado en la realidad, el pobre es la síntesis de este acontecimiento salvífico que llama urgentemente a 
la conciencia de la Iglesia (Cfr. Lucas 16, 19-31). La elucubración de los conceptos queda rebasada ante la existencia de los hombres y mujeres de este continente, los cuales se establecen como criterio para percibir el acontecer de la salvación iniciada en la historia. El futuro de Dios como donación salvífica empieza su actuar concreto en la capacidad eclesial para dejarse incluir en la realidad del pobre. La transmutación del acto salvífico, escatológico, la hace Medellín pasando de la Iglesia que acoge, a la Iglesia que es acogida en una historia más amplia, en un rostro concreto, en una persona pobre. Por lo tanto,

Debemos agudizar la conciencia del deber de solidaridad con los pobres, a que la caridad nos lleva. Esta solidaridad significa hacer nuestros sus problemas y sus luchas, hablar por ellos. Esto ah de concentrarse en la denuncia de la injusticia y la opresión, en la lucha cristiana contra la intolerable situación que soporta con frecuencia el pobre... (Celam, 1968, XIV-10).

\author{
Del más allá al más acá: \\ la escatología como acontecer histórico-salvífico \\ "Tener fe en el Dios de la Encarnación, \\ es proseguir su causa en la historia humana, \\ luchando contra todo aquello que le robe \\ al hombre su dignidad, tratando de poner los \\ medios necesarios para que el mundo sea \\ un espacio más humano, y en este sentido, más divino".
}

P. Alberto Ramirez

\title{
La historia como acontecer escatológico de Dios
}

La Conferencia de Medellín marcó un hito en el quehacer teológico de América Latina, a partir de allí la experiencia y la reflexión cristiana quedaron encarnadas en el devenir propio de los pueblos, mostrando así un camino 
vinculante entre teología y realidad. Este esfuerzo por "recepcionar" el espíritu del Concilio Vaticano II, abrió la puerta para que la Escatología se comprendiera de manera nueva, pasando de la estructura dogmática al devenir propio de la realidad de los hombres y mujeres de este continente. De esta manera, "como en el caso del Concilio, también en el caso de la Conferencia de Medellín tenemos que afirmar que no se trata de un punto de llegada en nuestra historia eclesial sino de un punto de partida" (Ramírez, 2012, p. 167).

En este marco referencial, Medellín y sus presupuestos teológicos que parten de la realidad, brindan a la Escatología un significado más real, es decir, existencial y vinculado directamente con la historia. La brecha resultante de la concepción neoescolástica propia de la teología europea durante el siglo XX, queda superada en Medellín. De la geografía ultraterrena y la especulación de otro mundo, se pasa a la acogida del don salvífico ya dado en la historia. Es el cambio de paradigma que Rahner expresa así,

El cristiano, a juzgar también por la manera de las afirmaciones escatológicas en el Antiguo y el Nuevo Testamento, está siempre tentado a leer e interpretar las afirmaciones escatológicas del cristianismo como reportajes anticipativos de un futuro que está por venir. Con ello se enreda casi a la fuerza en problemas y dificultades en lo que respecta a la credibilidad de una afirmación escatológica así leída, en dificultades que a la cosa misma no lleva inherentes por necesidad (2007, p. 496).

Este cambio necesario lleva a recomprender la Escatología como una hermenéutica cristiana de la historia. La lectura fatalista propia de las ideologías imperantes del siglo XX se agota en sí misma, siendo incapaz de dimensionar íntegramente este fenómeno antropológico en clave de futuro. La historia asumida por Dios en la Encarnación no es una frase romántica que ayuda a soportar la dureza de la existencia, sino todo el proceso fenomenológico que se constata en la realidad leída desde la fe. La historia como revelación de la salvación, la capta Ignacio Ellacuría en los siguientes términos cuando se refiere a la teología de la liberación,

Las características especiales de la teología de la liberación tampoco fluyen de que su objeto primario fundamental sea lo político ni siquiera 
la liberación entendida de modo integral. Fluyen más bien del "lugar" cristiano y epistemológico en el cual la teología se sitúa, de su opción preferencial por los pobres y de su propósito de que las virtualidades del reino de Dios se pongan al servicio de la salvación histórica del hombre, poniendo eso sí esta salvación en la más estrecha relación posible con lo que es la salvación cristiana del hombre y del mundo (1990, p. 325-326).

El Dios revelado no es una fuerza que está más allá del cosmos, no es un fugitivo desentendido de su obra. El Dios revelado es existencia concreta, realidad dada y acontecida que hace historia en plural, de esta manera, "Dios se ha hecho hombre en Jesús: él se ha expresado en este hombre y en este hombre se ha ligado para siempre a la humanidad" (Grün, 2007, p. 31).

La Encarnación ${ }^{15}$ y no la metafísica es el auténtico camino de la revelación de Dios en la historia humana. Dios no revela, Dios se revela aconteciendo como don en salida de sí; Dios es revelándose, se da y este dar concretiza en el ser humano la captación del revelado (Cfr. Dei Verbum, 2). Volver a la originalidad de la recepción de la revelación, es decir, la capacidad para captarlo que brota del interior del hombre es la posibilidad de reivindicar su imagen originaria no agotada en la caducidad. La recepción de esta revelación es la historia humana como realidad vinculante, por lo tanto,

Cuando se alcanza históricamente a Dios -y lo mismo vale decir cuando se alcanza personalmente a Dios-, no se abandona lo humano, no se abandona la historia real, sino que se ahonda en sus raíces, se hace más presente y eficaz lo que estaba ya efectivamente presente. Puede separarse Dios de la historia, pero no puede separarse de Dios la historia. Dios es trascendente, entre otras razones, no porque se ausente, sino porque se hace libremente presente (Ellacuría, 1990, p. 328).

15 El tema de la Encarnación es definitivo en la comprensión del misterio revelado. Es el centro absoluto del acontecer salvífico de Dios como cercanía solidaria con el ser humano. Bayron Osorio en su libro Kénosis y donación (2015), afirma lo siguiente: la Encarnación y todo el acontecimiento Jesús, es la manifestación de Dios en cuanto amor, materializado en la entrega absoluta. Son la expresión del amor dándose y presente en la realidad efectiva del vaciamiento de sí del Hijo en orden a la redención y salvación (p, 122). 
Ante las mutiladas comprensiones antropológicas, el Dios revelado acontece como respuesta desde las entrañas del mundo (Cfr. Juan 1, 1-18). Humanándose hasta el extremo da su respuesta, aleja de sí el fatalismo apologético que se encierra en conceptos la realidad y abre el hecho vital dinámico como don en gasto. El camino elegido por Él es la existencia y una auténticamente humana. De esta manera, "el enigma de la condición humana se esclarece definitivamente a la luz de la revelación realizada por el Verbo divino". (Benedicto XVI, 2010, p. 16). Esta respuesta para el hombre se da porque es "capax Dei" (capaz de Dios), pero al mismo tiempo y de manera contundente, se da porque el Dios de los cristianos es "capax hominis" (capaz del hombre) (Gesché, 2002, p. 237). En esta unidad indisoluble, se da la experiencia viva y real de Dios en la historia, un Dios carnal.

El esclarecimiento del acontecimiento encarnacionista permite reelaborar la imagen de Dios desde nuestro ser, permite resituarnos en la historia como lugar teológico por excelencia. La finitud consciente y asumida acontece como Evangelio y el presupuesto definitivo para comprender al Dios revelado. Dios y el hombre se reconocen, ambos acontecen en la cercanía íntima de la finitud. En el don del uno para el otro quedan transformados, afectados hondamente hasta el punto de que ya no serán los mismos. De esta manera,

El misterio de la encarnación es central, de manera que, desde ese misterio insondable, Dios empieza a ser para nosotros diferente. Porque, en la encarnación, Dios se funde y se confunde con lo humano. Hasta el punto de que ya no es posible ni entender, ni acceder a Dios, prescindiendo de lo humano y, menos aún, entrando en conflicto con lo humano, con todo lo que es verdaderamente humano y, por tanto, con todo lo que nos hace felices a los humanos, nos realiza, nos perfecciona y nos hace gozar y disfrutar de la vida humana en toda su amplitud y hermosura (Castillo, 2005, p. 30-31).

La fe como proceso de Encarnación, permite abrir el horizonte del hombre y desplegarlo hacia una mirada más humana, tan humana como la de Dios en Jesús. Este proceso de deconstrucción teológica y antropológica permite generar un dinamismo que resitúe al hombre de cara al futuro asumiendo la historia. De esta manera, "la historia se convierte así en 
probación de Dios porque es en sí misma mostración de Dios, y sólo en la historia es captado Dios como es en relación al hombre y el hombre como es en relación con Dios" (Ellacuría, 1990, p. 333).

El presente está cuajado de futuro desde la opción hermenéutica de la fe, por eso Dios y el hombre acontecen en la historia, ambos caminan, ambos se encuentran, ambos están en marcha. La Encarnación ha saturado la historia de infinito, el futuro de Dios es la humanización plena en la carne del Hijo. Aquí está la revolución que permite captar a Dios desde las entrañas de esta tierra. El ser humano no va hacia el cielo, el ser humano va hacia el futuro que es la Escatología plena dada como don presente, más aún, "el cielo está en la tierra, porque Dios está es aquí. Dios no está fuera del universo. Está en el universo, todos estamos allí con él, en la misma obra de él. ¡Eso es el cielo!” (Baena, 2017, p. 144).

Encarnación e historia son los fundamentos de la Escatología. La Conferencia de Medellín asume este presupuesto dando un vuelco radical en la interpretación de la salvación. La Escatología no viene de afuera, no está reservada en otro mundo, la Escatología como don de Dios, como futuro de Dios al hombre, es la experiencia del "acto salvífico continuo" que acontece en todo ser humano. Dios implícito en la historia lo único que tiene es una inagotable capacidad de salvación, este es su don máximo a partir de Jesús. Con base en esto,

Por primera vez en este mundo se nos ha dicho que Dios está implícito en todo ser humano y en toda la creación. Si esto se toma en serio habría que concluir que Dios de por sí es infinito, sin embargo, al crear de esa manera tan extrańa e incomprensible ante nuestra racionalidad, se someta a ese mundo, a ese universo que él ha creado con sus leyes autónomas y, por tanto, a su espacio temporalidad. El creador sometido a la autonomía de un universo limitado. En esta manera tan rara, tan absurda desde nuestra racionalidad, es donde se percibe su misteriosa manera de crear: el Misterio de Dios. Esta es la nueva percepción de Dios creador que se nos revela en Jesús (Baena, 2017, p. 18). 


\section{La Escatología como alteridad salvífica}

La toma de conciencia que ha ido haciendo progresivamente la teología desde el siglo XX, permite ver en Medellín un punto de anclaje en la realidad $^{16}$, este presupuesto para la Escatología es de suma importancia, pues permite reafirmar la evolución histórica en la comprensión del misterio de Dios revelado, lo cual genera una nueva interpretación de estos postulados en clave existencial. La esperanza como don de Dios se traduce en una vida con futuro, en palabras de Alberto Ramírez,

La esperanza es la actitud humana que, ante la realidad del futuro, nos permite vivir la vida presente de manera positiva, optimista, feliz. Para los cristianos, la esperanza es la única actitud posible para mirar hacia el futuro porque estamos convencidos de que el Dios en quien creemos es el cielo hacia el cual nos encaminamos, pero también nuestro por-venir (2008, p. 236).

La Escatología como el futuro de Dios para el ser humano, se despliega en la realidad aconteciendo desde la Iglesia entendida como comunidad de fe, hombres y mujeres impulsados por el Espíritu del Resucitado capaces de futuro en la historia. Este compromiso liberador y salvífico que a partir de Medellín se establece como imperativo categórico para el cristiano, recepciona la Escatología inspirada por el Concilio, a saber,

La Conferencia de Medellín asumió la inspiración del Concilio en todos sus aspectos: es entonces completamente comprensible que también la sensibilidad escatológica que caracterizó al Concilio se perciba en la documentación de la asamblea episcopal latinoamericana. Una exégesis cuidadosa de los textos nos lo demuestra. Sin embargo, el hecho de la recepción original de la inspiración conciliar, que subrayó la temática de

16 Aquí aparece la recepción más clara que hace la Conferencia Episcopal de Medellín, partiendo de la realidad dimensiona de manera amplia y práctica el quehacer de la teología y de la experiencia de fe. El camino abierto por la Constitución Pastoral Gaudium Et Spes se materializa en la opción de Medellín por hacer una teología desde la vida. 
la misión pastoral de la Iglesia en el mundo actual ("en la actual situación de América Latina"), nos permite comprobar el sentido en el que se asumió propiamente en Medellín la dimensión escatológica de la Iglesia. Ella aparece como una dimensión constitutiva del compromiso profético de nuestras Iglesias en relación con la construcción de un mundo mejor, edificado sobre el fundamento de la promoción social, de la justicia y de la paz (Ramírez, 2008, p. 245).

La dimensión histórica de la Escatología permite una captación más amplia de Dios. El fenómeno salvífico deja de ser especulativo y antagónico a la realidad, y pasa a establecerse en la continuidad dinámica de la vida. Dios mismo desde las entrańas del mundo impulsando la realidad y en ella al ser humano hacia el futuro. El lugar de Dios es el hombre erigiendo un mundo más humano, esto es la salvación en acto. En otras palabras, "el acto creador y el acto salvador es el mismo, porque crearlo es llevarlo hasta el destino que Él quiere y es llevarlo a la infinitud" (Baena, 2017, p. 141).

La Escatología desde este ángulo genera todo un dinamismo existencial que se sintetiza en el ser humano. La vida en su constante dinámica permite una progresión de sentido que va ampliando la visión antropológica, pues no es solamente identificar el "ser en el mundo", sino, con el ser situarse en la praxis de futuro intrahistórico distinto. El ser humano siempre será el lugar originario desde el cual parte el acto salvífico del Dios revelado que se extiende a todas las realidades de la historia humana. Por consiguiente,

Toda escatología es escatología de la liberación de los seres humanos de las cadenas del pecado, la muerte y la ruptura de la comunión con Dios y con los otros seres humanos. También es escatología de la liberación de un mundo injusto, maligno, que está llegando a su fin inminente, como en la escatología apocalíptica, una liberación de los apegos de este mundo, como en la escatología ascética, o una liberación de la normalidad con la que aceptamos las estructuras de opresión y exclusión presentes en nuestras sociedades, como en la escatología ética (Castrillón, 2016, p. 178).

Por otra parte, Medellín invita a pensar y a vivir la Escatología desde la alteridad en clave de donación. La auténtica salvación se hace efectiva en la opción por el otro. Esta premisa permite comprender que "fuera del hombre 
no hay salvación”. Esta opción de Dios en Jesús, nos incluye en un amor que sobrepasa el límite, su donación de amor rompe con el determinismo de la muerte a la cual el ser humano está abocado. A partir de la Encarnación se establece el hecho salvífico en clave de alteridad, la escatología es Kénosis ${ }^{17}$.

La Escatología como donación sin límite hace presente por medio de la existencia el ágape, del concepto se pasa a la experiencia por la alteridad. La salvación iniciada en la Encarnación alcanzará su culmen en la Pascua, a través de la cual, la muerte como realidad antropológica no será la conclusión de la vida, sino la amplitud total de lo acontecido intrahistóricamente en clave salvífica, es la comprensión teológico-celebrativa que hace el prefacio I del ritual de exequias, "porque la vida de los que en ti creemos, Señor, no termina, se transforma”.

Ante el exceso de una entrega total el amor es el camino de recepción. El Dios revelado se dona como principio de su actuar en el mundo, su constante salida hacia los otros (seres humanos) es la constatación de la Escatología como libertad (Cfr. Éxodo 3, 7-12). Por tanto,

El amor se da y se da sin condiciones. El donador se abandona completamente a la donación hasta coincidir donador y donación. Y darse completamente sin precomprensiones o comprensiones es amar. El amor excluye al ídolo, pues en el movimiento del darse, el sujeto no cubre al otro con su conceptualidad sino que se abandona totalmente a él, hasta dejarse determinar en esta donación. Ya no se tata de pesar a Dios desde la conceptualización humana, sino desde el donarse (Arboleda, 2013, p. 20).

Respecto a lo anterior, la Escatología se torna así en la apertura de la existencia a una relación fundada en la esperanza ${ }^{18}$. Dios como don originario

17 Kénosis: tiene su origen en uno de los pasajes de la Carta a los Filipenses, específicamente en el "Himno Cristológico" (2, 6-11) citado por San Pablo. En el

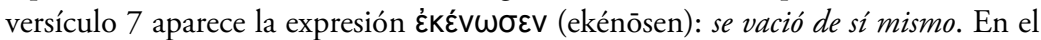
lenguaje teológico se utiliza para referirse al "abajamiento" o "vaciamiento" del que se habla en Flp 2,7. (Osorio, 2015, p. 27).

18 La esperanza como opción existencial, como don para situarse y asumir la vida, es ampliamente estudiada en la obra del teólogo alemán Jürgen Moltmann, Teología 
se capta en alteridad, a partir de la Encarnación la relación se vuelve salvación en un amor dilatado. De ahí que,

El amor no se da sino abandonándose, transgrediendo continuamente los límites del propio don, hasta trasplantarse fuera de sí. La consecuencia es que esta transferencia del amor fuera de sí mismo, sin fines ni límites, impide inmediatamente que se deje agarrar en una respuesta, en una representación, en un ídolo. Es típica de la esencia del amor -diffusivum sui- la capacidad de sumergir, así como una marea sumerge las murallas de u puerto extranjero, toda limitación, representativa o existencial del propio flujo; el amor excluye el ídolo, o mejor, lo incluye subvirtiéndolo (Marion, 2010, p. 74-75).

Finalmente, la Escatología que entra en el dinamismo de la vida escapa al concepto y se funda en la alteridad saturada de ágape. La Conferencia de Medellín da un paso cualitativo que sigue siendo vigente hoy, recuperar la opción por Dios en la opción radical por el ser humano y su realidad, sólo desde este ángulo es posible seguir sosteniendo la Escatología no como discurso, sino como experiencia que fundamenta la existencia en un nosotros saciado de futuro. En definitiva,

El hombre mismo es ese claro donde se da la manifestación más primera y esencial del ser mismo, y olvidar esto es olvidar el ser mismo del hombre: ser el lugar donde se manifiesta el Ser. Dios se manifiesta en el hombre, vive en el hombre, se da en el hombre, es la razón de ser del hombre. Exagerando un poco, se puede decir que cuando mure un hombre, es Dios mismo el que muere allí (Arboleda, 2013, p. 25).

de la esperanza (2006). Dice: la fe puede y debe dilatarse hasta la esperanza allí, sólo allí donde, con la resurrección del crucificado, están derribadas las barreras contra las que se estrellan todas las esperanzas humanas. La esperanza de la fe se transforma en apasionamiento por lo posible (p. 25). 


\section{Referencias}

Alviar, J, J. (2011). Escatología. Navarra, España: Ediciones Universidad de Navarra (EUNSA).

Arboleda, C. (2013). El giro teológico: nuevos caminos de la filosofía. Medellín, Colombia: Editorial Universidad Pontificia Bolivariana.

Baena, G. (2017). Revelación, Teología y Vida Cristiana $N^{\circ} 2$. Medellín, Colombia: Fundación Centro de Fe y Culturas.

Baena, G. (2014). Fenomenología de la Revelación. Navarra, España: Editorial Verbo Divino.

Benedicto XVI. (2006). Audiencia General: la Tradición, comunión en el tiempo. Roma, Italia.

Benedicto XVI. (2010). Exhortación Apostólica Postsinodal Verbum Domini. Navarra, España: Editorial Verbo Divino.

Boff, L. (2011). Hablemos de la otra vida. Santander, España: Sal Terrae.

Cadavid, A. (2010). El camino pastoral de la Iglesia en América Latina y el Caribe. Del primer Concilio Plenario a Aparecida. Bogotá, Colombia: Editorial San Pablo.

Carrasquilla, F. (1996). Escuchemos a los Pobres. Aportes para una antropología del Pobre. Medellín, Colombia: Centro de Investigaciones Sociales.

Castillo, J, M. (2005). La ética de Cristo. Bilbao, España: Desclée De Brouwer.

Castrillón, J. F. (2016). Escatología de la Liberación. Pensamiento utópico y teología de la liberación. Bogotá, Colombia: Editorial Pontificia Universidad Javeriana.

Celam, (2014). Las Cinco Conferencias Generales del Episcopado Latinoamericano. Bogotá, Colombia: Centro de publicaciones - Celam.

Concilio Vaticano II. Constituciones, Decretos y Declaraciones. (2012). Madrid, España: Biblioteca de Autores Cristianos.

Dussel, E. (2011). Filosofía de la liberación. México: Fondo de Cultura Económica.

Ellacuria, I., y Sobrino, J. (1990). Mysterium Liberationis. Conceptos fundamentales de teología de la liberación. Madrid, España: Editorial Trotta.

Francisco. (2013). Exhortación Apostólica Evangelii Gaudium. Navarra, España: Editorial Verbo Divino. 
Francisco. (2017). Francisco, Visita Apostólica a Colombia. Homilias y Discursos. Bogotá, Colombia: Editorial San Pablo.

Freire, P. (1967). Educao como practica do libertade. Río de Janeiro, Brasil: Paz e Terra.

Freire, P. (1985). Pedagogía del oprimido. Montevideo, Uruguay: Siglo XXI Editores.

Galeano, A. (2017). El drama histórico de la obra salvadora. Una historia de gracia $y$ de pecado. Bogotá, Colombia: Editorial San Pablo.

Galeano, A. (2015). Visión cristiana de la historia, ensayo de escatología. Bogotá, Colombia, Editorial San Pablo.

Galeano, A. (2013). Un acercamiento a las corrientes de la teología católica en nuestro tiempo. Movimientos e ideas. Cuestiones Teológicas, 40(94), 345-374.

Gesché, A. (2002). Jesucristo. Dios para pensar VI. Salamanca, España: Ediciones Sígueme.

Gibellini, R. (1998). La teología del siglo XX. Santander, España: Sal Terrae.

Grün, A. (2007). La fe de los cristianos. Buenos Aires, Argentina: Editorial San Pablo.

Latourelle, R. (2016). Teología de la Revelación. Salamanca, España: Ediciones Sígueme.

Marión, J. L. (2010). Dios sin el ser. Vilaboa, Pontevedra: Ellagro.

Mesters, C. (2009). Dios, ¿dónde estás? Una introducción práctica a la biblia. Navarra, España: Editorial Verbo Divino.

Moingt, J. (2017). Creer a pesar de todo. Conversaciones libres sobre el presente y el futuro del catolicismo. Bilbao, Espańa: Ediciones Mensajero.

Moltmann, J. (2004). La venida de Dios. Escatología cristiana. Salamanca, España: Ediciones Sígueme.

Moltmann, J. (2006). Teología de la esperanza. Salamanca, España: Ediciones Sígueme.

Rahner, K. (2007). Curso fundamental sobre la fe. Introducción al concepto de cristianismo. Barcelona, España: Herder.

Ramírez, A. (2008). La Conferencia de Medellín y la teología de la esperanza. Cuestiones Teológicas, 35(84), 235-254.

Ramírez, A. (2012). En los cincuenta años de la inauguración del Concilio Vaticano II. Medellín, Colombia: Editorial Universidad Pontificia Bolivariana. 
Ramírez, A. (2013). Cuestiones de Teología Fundamental. Revelación y Fe. Medellín, Colombia: Editorial Universidad Pontificia Bolivariana.

Osorio, B. (2015). Kénosis y Donación. Una clave de lectura del Acontecimiento Jesús. Medellín, Colombia: Editorial Universidad Pontificia Bolivariana.

San Juan de la Cruz - Obras Completas. (2007). Subida al monte Carmelo. España: Monte Carmelo.

Torres Queiruga, A. (1995). ¿Qué queremos decir cuando decimos infierno? Bilbao, España: Sal Terrae.

Torres Queiruga, A. (2008). Repensar la Revelación. Madrid, España: Editorial Trotta.

Torres Queiruga, A. (2011). Repensar el mal. De la ponerología a la teodicea. Madrid, España: Editorial Trotta. 